\title{
Health Awareness and Practice of Early Breast Cancer Detection: An Intervention Study in a Group of Working Egyptian Women
}

\author{
Hend M. Mohamed MD ${ }^{1}$, Nadia A. Montasser MD ${ }^{1}$, Omar A. Farouk MD ${ }^{2}$, Nermeen A. Niazy MD \\ ${ }^{1 *}$,Abdel-Hady El-Gilany MD ${ }^{1}$ \\ ${ }^{1}$ Public Health and Community Medicine Department, Faculty of Medicine, Mansoura University, \\ Egypt. ${ }^{2}$ Surgical Oncology Department, Oncology Center, Faculty of Medicine, Mansoura \\ University, Egypt
}

\begin{abstract}
:
Background: Early breast cancer detection can effectively improve treatment chance, survival and quality of life. Health awareness and screening are the main pillars of early detection. Objectives: To compare the pre- and post-intervention knowledge, attitude and practice regarding breast cancer and its early detection. Methods: This is a pre-postinterventional study carried out on 120 women employees voluntarily participated in the breast cancer screening campaign implemented in Mansoura University. Champion's Health Belief Model (HBM) Scale, knowledge questionnaire and breast self-examination (BSE) observation checklist were applied before and after the intervention. Intervention included a lecture, video and brochure containing information about breast cancer definition, magnitude of the problem, risk factors, early detection, signs and symptoms, screening and BSE. Results: The pre-intervention median scores of general knowledge, BSE knowledge and practice were five, three and zero; respectively. Only the general knowledge score is significantly higher in highly educated employees. These scores increased significantly in the post-intervention. The HBM score was $32.85 \pm 7.23$ in the pre-intervention and significantly increased to $43.73 \pm 5.49$ post-intervention. Conclusion: Women had poor knowledge in all domains studied. The intervention is effective in raising awareness of women employees about breast cancer and early detection. It may be used as a template for wide scale application in different settings
\end{abstract}

Key Words: Breast cancer, knowledge, health belief model, breast self-examination (BSE).

\section{Introduction:}

Breast cancer is a major public health problem worldwide. It is by far the world's most common cancer among women, and the most likely cause that a woman will die from cancer worldwide. ${ }^{(1)}$

The most common cancer among females was estimated to be breast cancer in Egypt. Global Cancer Observatory (GLOBOCAN) 2012 reports of cancer in Egypt, demonstrated that breast cancer among Egyptian females accounts for $33.5 \%$ of all new cancer cases among females with age standardized rate representing 49.5 per 100,000 (2) Breast cancer survival rate in developing countries is generally poorer than in developed countries, primarily as a result of delayed diagnosis. ${ }^{(3)}$

*Correspondent author: nermeenniazy@yahoo.com 
So, breast cancer early detection can effectively improve the chance of diagnosing cancer at early stages, resulting in successful treatment with improvement of survival rate and quality of life. ${ }^{(4)}$ Early detection of breast cancer depends mainly on two main pillars; health awareness and screening. Screening activities of breast cancer include breast selfexamination (BSE), clinical breast examination (CBE) and mammography ${ }^{\cdot(5)}$

The American cancer society recommended that, it is important for every woman to be conscious of how their breasts normally look and feel then report immediately any deviations in the appearance or feel of their breasts to their health care provider . ${ }^{(6)}$ Studies conducted in developing countries have established BSE as one of the most reasonable and feasible approaches in early detection of breast cancer. ${ }^{(7)}$ As compared to CBE and mammography which require hospital visits and specialized equipment/technical expertise; breast self-examination is cost-free, simple and noninvasive intervention carried out by women themselves. ${ }^{(8)}$

The poor knowledge and wrong beliefs about prevention of breast cancer among women were found to be responsible for the underestimation and negative perception of the curability of the early detected breast cancer and of the efficacy of the screening tests. ${ }^{(9)}$ One of the best models that is efficient in studying preventive behaviors in cancer is the Health Belief Model (HBM). The HBM is psychosocial models that accounts for health behaviors by identifying factors associated with individuals' beliefs which influence their behaviors ${ }^{(10)}$ The main constructs include perceived susceptibility, perceived severity, perceived benefits, perceived barriers, cues to action and self-efficacy. It is hypothesized that the HBM would be predictive of women's intentions to perform BSE. ${ }^{(11)}$ To the best knowledge of authors' knowledge, only a study was done on employee women in Egypt and no study utilizing HBM in breast cancer awareness campaigns. ${ }^{(11)}$

The present study aims to assess the effect of an intervention on knowledge and attitude (using HBM main constructs) towards breast cancer and its early detection and the practice of BSE among a sample of female employees working at Mansoura University, Egypt.

\section{Methods:}

The present study was conducted in Mansoura University between the periods from July 2014 till February 2015, on female employees with exclusion of those with previous personal history of breast cancer and pregnant or lactating at the time of the study. 


\section{Sampling:}

The study population is all women participating in the breast cancer awareness campaigns implemented by the Faculty of Medicine among women employees of Mansoura University. All women fulfilling the inclusion criteria (working for one year or more) were invited to participate .A total of 137 women participated in the intervention program, however only 120 of them completed the follow up interview after a month with response rate of $87.6 \%$. The non-responders were either in vacation or lost further interest in the study so they were excluded from the analysis.

\section{Ethical consideration}

From each participant sharing in the study a verbal consent was obtained after assuring confidentiality. The consent was obtained after explaining every step to the participants. The study protocol was approved by the IRB of Faculty of Medicine, Mansoura University.

\section{Study design:}

An interventional study (pre-post) study was carried out in 3 phases:

Phase I (Descriptive Phase): It aimed to assess knowledge and attitude among the studied sample about breast cancer and breast cancer screening, evaluate BSE practice among women who performed it before the study using an interview questionnaires;

1- The HBM questionnaire included: Socio-demographic characteristics and Champion's Health Belief Model Scale (CHBMS) which was designed to assess and compare attitude towards breast cancer and breast self-examination pre and post intervention. It is a 42-item instrument designed to obtain baseline data. The CHBMS related to BSE was revised in 1997, the revised scales reflected internal consistency ranging from 0.75 to 0.88 and test reliabilities from 0.59 to 0.72 . The scale demonstrated construct validity, confirmed through exploratory and confirmatory factor analysis. ${ }^{(12)}$

The Arabic version was tested for content validity by a jury of 5 experts of public health. The content validity ranged from 0.71 to 0.92 for different items. The internal consistency (reliability) was test on ten women (of less than one year duration of work) the Cronbach's alpha was found to be 0.79. The CHBMS incorporates the six basic concepts contained in the HBM namely; perceived susceptibility ( 4 items), perceived severity ( 11 items), perceived benefits ( 5 items), perceived barriers( 6 items), cues to action ( 10 items) and self-efficacy ( 6 items) as they relate to breast cancer, BSE ${ }^{(13)}$,(14) A five-point Likert Scale was 
used to measure responses which was modified to three-point; agree, indifference and disagree.

2- Knowledge questionnaire about breast cancer and breast cancer early detection:

The internal consistency of the study tool was estimated on the basis of Cronbach's Alpha $(\alpha=0.68)$. The Cronbach's alpha of the Arabic version was 0.72. Collectively the knowledge domain was comprised of 22 items; 3 asking about general knowledge about breast cancer, 6 about possible early clinical presentation of breast cancer, 12 about possible risk factors of breast cancer and one about source of information of breast cancer and BSE. Modification was done to the possible risk factor to add nulliparity and change the risk factor "large breast" by "obesity" so after modification the total knowledge equals 23 items. Knowledge about screening of breast cancer included 15 items. Internal consistency of this tool was estimated on the basis of Cronbach's Alpha ( $\alpha$ $=0.809)$. The Cronbach's alpha of the Arabic version was 0.83 .

3- Observational checklist about breast self-examination had 14 items. Women practicing BSE were asked to repeat in front of the researcher in a private closed room individually. One mark for the correct performance and ' 0 ' mark for the incorrect performance, the highest possible score was 14. (14) The internal consistency of the observational checklist was $\mathrm{r}=0.96$.

Phase II (Interventional Phase: application of health education program): It aimed to provide accurate knowledge regarding breast cancer and breast cancer screening, acquiring correct practical skills. The program was in the form of lecture, video and brochures followed by group discussion. The program was carried out at the participants' workplace for more convenience and to be carried out on small groups (8-10 female /session).Each session last about 45 minutes. The health education messages directed towards:

a) Breast cancer (definition, magnitude of the problem worldwide and in Egypt, most common age for occurrence, symptoms of breast cancer, possible risk factors, protective measures that help reducing risk of breast cancer and prognosis).

b) Breast cancer screening (definition, methods of screening and importance).

c) Breast self-examination (definition, importance, frequency, timing, proper age to start, proper technique including visual inspection and palpation and possible warning signs that must be informed to the physician). 
d) Addressing possible motivating factors towards BSE practice (e.g. curability of the disease).

e) Addressing possible factors that may hinder practicing breast self-examination and try to minimize their effect by provision of solutions (e.g. early detection of breast cancer greatly enhances the prognosis).

Phase III (Post Intervention Descriptive Phase):The participants were given one month to perform breast self-examination at home at a mutually agreed fixed day and respond again to the same interview questionnaire and observational checklist in the post-test session to assess change in knowledge/ attitude towards breast cancer screening and BSE practice among the studied females.

*All study tools (questionnaire, checklist and health education videos) were translated into Arabic by two researchers .The contents of correctness of translation were approved by a consensus of 7 juries experts in Public health and Oncology (copies of the materials are available upon request).

\section{Statistical analysis}

The completed questionnaires and observational checklist were subjected to review and the collected data were coded, processed and analyzed through SPSS (V.16). Descriptive statistics was applied using frequency analysis to detect mean \pm SD (for parametric data) and median (for non-parametric data) of each variable in the pre- and post -intervention. Paired t-test and Wilcoxon sign tests were used to compare knowledge, practice and HBM scores pre and post-test. Kruskall wallis test and one way ANOVA were used to study association between the socio-demographic characteristics of the study participants with the pre-intervention knowledge, attitude and practice. P-value was estimated to be significant if $\leq 0.05$.

\section{Results:}

Among 120 studied female employees in Mansoura University (61.7\%) were less than 30 years , $(53.3 \%)$ were university graduate and $(94.2 \%)$ had negative family history of breast cancer. Before application of health education program, median knowledge scores were low regarding breast cancer and BSE knowledge in pre- intervention compared to post -intervention median score (5,3 and 9,5 respectively) with high statistically significant difference comparing pre- and post- intervention [table 1].

All constructs of Health Belief Model showed improvement of total scores in posttest than pre- test $(4,12,9,2$ and 8.33 compared to $5,13,12,8$ and 9.19) for perceived 
susceptibility, severity, cues to action, self-efficacy and perceived benefits respectively .Also perceived barriers showed improvement of posttest median score than pre intervention score (3 compared to 1 , respectively). There were statistically significant differences between the pre and post-intervention scores for all constructs of HBM except for perceived severity of breast cancer [table 2].

BSE practice was found to be carried out among only 28 participants before carrying out the study. A high statistically significant improvement of BSE practice was found while comparing the pre- and post-test scores [table 2].There was no association between socio demographic characters and knowledge, attitude and practice scores except for educational level which had a statistically significant association with breast cancer general knowledge [table 3].

The majority of the participants who were aware of breast cancer and BSE obtained their information through their peers and friends, while mass media had a minor role reported by only $(7.5 \%)$ of them. Health care workers also were reported by only (22.5\% and $43.3 \%)$ of the participants as a source of information for breast cancer and BSE, respectively (data not shown in tables).

\section{Discussion:}

Breast cancer is one of the leading causes of death among women worldwide and in Egypt. Early detection methods, such as mammography, clinical breast examination and breast self-examination; continue to play an important role in the reduction of deaths from breast cancer in the absence of primary prevention strategies. Breast selfexamination provides a relatively simple, low cost method of early detection that can be performed more frequently than mammography or clinical breast examination ${ }^{\text {(4) }}$

Before application of health education program, knowledge scores before intervention show lower median score than post intervention scores .These results are in consistent with the study carried out by a study in Ain Shams University on female employees (11), who found that only (10.6\%) of the participants had satisfactory knowledge about breast cancer, its early detection, possible early clinical presentation and risk factors. On the contrary, in a study carried out to assess awareness of breast cancer among Irish population, they demonstrated that (87\%) of the female participants were aware of breast cancer definition, incidence and value of early detection. ${ }^{(15)}$ 
After application of health education program, there was a statistically significant improvement in total knowledge, attitude and practice scores. This significant improvement also noticed in many other studies. ${ }^{(16-20 \mid)}$. These findings emphasis on the role of health education program in raising awareness which in turn motivate females towards early detection which help improving prognosis, better quality of life and increased survival of breast cancer.

In the present study, perceived severity of breast cancer showed the highest score while perceived self-efficacy was the least. Compared to our results, the highest mean score as reported by in the study carried out on Turkish students was to perceived selfefficacy. (21) Among socio-demographic characteristics only educational level showed a statistically significant association with the pre-intervention knowledge .This is in agreement with the study carried out in Turkey, as they reported that (92.4\% and $75.5 \%)$ of the participants with university education, had good knowledge regarding breast cancer early detection and BSE, respectively.(22) This is may be explained by the possibility that females with higher educational level are more concerned with health issues .(23)Similarly, a study found that higher education level was associated with higher perceived benefits of BSE. ${ }^{(24)}$

Concerning the main source of information about breast cancer and BSE in the present study it was found that peers and friends were reported by about $(93.3 \%$ and $44.2 \%$ ) of the participants as a source of information of breast cancer and BSE ,respectively .This is in consistent with the study carried out on female employees in Ain Shams University who found that about (50\%) of the participants' source of information were from their peers with the lowest reported source of information was health care workers. This is may be due to long time spent by working women at their workplace that help sharing information including medical issues with their peers.(11)

Mass media was found to play a minor role as the participants' source of information especially for BSE in our study. In contrast to our results was the study carried out in Nigeria who demonstrated that mass media was the most common source of information for their participants regarding breast cancer knowledge. So the deficient role of mass media and health care providers in this respect should be stressed on with increased frequencies of educational campaigns. ${ }^{(25)}$

Conclusion:In conclusion the intervention is effective in raising awareness of women employees about breast cancer and early detection. It may be used as a template for wide 
scale application in different settings this could be applied through a comprehensive breast cancer health education program in their worksite. This could be applied through a comprehensive breast cancer health education program in their worksite.

\section{Study limitations:}

Single center study on highly selective setting of group of working women, its results cannot be generalized into general population of women in the community.

\section{Funding:}

Author(s) disclose no funding sources.

\section{Competing Interests:}

Author(s) disclose no potential conflicts of interest.

\section{References:}

1. Azim H, Ibrahim A. Breast cancer in Egypt, China and Chinese: statistics and beyond. J Thorac Dis. 2014; 6(7): 864-866.

2. Elmore JG, Armstrong K, Lehman CD, Fletcher S W. Screening for breast cancer .The Journal of the American Medical Association.2005; 293(10):245-1256.

3. Al Saad SK , Al Sayed B . Early Breast Cancer Detection Is Higher Compared to Advanced Cancer. Bahrain Medical Bulletin .2012; 344.

4. Cancer prevention \& early detection facts \& figures 2008. American Cancer Society, Atlanta, Georgia, USA. 2008.

5. Baig M, Subramaniam V, Chandrasegar A, Khan T. A population based survey on knowledge and awareness of breast cancer in the suburban females of Sungai Petani, Kedah, Malaysia. IJCRIMPH .2011; 3, 670-679.

6. American cancer Society. Breast cancer facts \& figures2013-2014 Retrieved from: http://www.cancer.org/Research Cancer facts figures / Breast Cancer Factes / breast -cancerfacts-and-figures-2013-2014 (Last accessed 27/6/2014).

7. Omoyeni OM, Oluwafeyikemi PE, Irinoye OO ,Adenike O. Assessment of the Knowledge and Practice of Breast Self Examination among Female Cleaners in Obafemi Awolowo University, Nigeria. International Journal of Caring Sciences. 2014; 7 (1):239-250.

8. Mohammad FM, Bayoumi MM , Megahed M M . Efficacy of Instructional Training Program in Breast Self-Examination \& Breast Screening for Cancer among University Students .Public Health Research.2013 ; 3(3): 71-78. 
9. Sharifirad GR, Entezari MR, Kamran A, Azadbakht L. The effectiveness of nutritional education on the knowledge of diabetic patients using the health belief model. J Res Med Sci.2009; 14(1): 1-6.

10. Fikry FE, Helal HA, Awad LE, Mohamed HH. Breast cancer preventive behaviors. Academic journal of cancer research. 2012; 5(1):17-30.

11. Seif N, Aziz MA .Effect of breast self-examination training program on knowledge, attitude and practice of a group of working women. Journal of the Egyptian National cancer institute.2000; 12(2):105-115.

12. Champion VL. Revised susceptibility, benefits, and barriers scale for mammography screening. Research in Nursing\& Health .1999; 22(4):341-348

13. Champion VL. Instrument refinement for breast cancer screening behaviors. Nurs Res .1993; 42:138-143.

14. Champion VL, Scott CR. Reliability and validity of breast cancer screening belief scales in African American women. Nurs Res .1997; 46:331-337

15. McMenamin M, Barry H, Lennon AM, Purcell H, Baum M, Keegan D, McDermott E, O’Donoghue D, Daly L, Mulcahy H. A survey of breast cancer awareness and knowledge in a Western population: lots of light but little illumination. European Journal of Cancer. 2005;41(3):393-397

16. Ceber E, Turk M, Ciceklioglu M. The effects of an educational program on knowledge of breast cancer, early detection practices and health beliefs of nurses and midwives. J Clin Nurs.2010; 19(23):63-71.

17. Haji-Mahmoodi M, Montazeri A, Jarvandi S, Ebrahimi M, Haghighat S, Harirchi I. Breast self-examination: knowledge, attitude and practices among female health care workers in Tehran,Iran .The breast journal. 2002; 8(4):222-225.

18. Karayurt O, Özmen D, Çetinkaya AC. Awareness of breast cancer risk factors and practice of breast self-examination among high school students in Turkey. BMC Public Health.2008; 8:359.

19. Yavari, P. , Pourhoseingholi, M.A. (2007). Socioeconomic factors association with knowledge and practice of breast selfexamination among Iranian women. Asian Pac J Cancer Prev; 8(1):618-622.

20. Gurdal SO, Saracoglu GV, Oran ES, Yankol Y, Soybir GR. The Effects of Educational Level on Breast Cancer Awareness: A Cross-Sectional Study in Turkey. Asian Pacific Journal of Cancer Prevention .2012; (13):295-300. 
21. Yucel SC, Orgun F, Tokem Y, Avdal EU , Demir M. Determining the Factors that Affect Breast Cancer and Self Breast Examination Beliefs of Turkish Nurses in Academia. Asian Pac J Cancer 2014.

22. Gupta SK, Pal DK, Garg R, Tiwari R, Shrivastava AK, Bansal M. Impact of a health education intervention program regarding breast self-examination by women in a semi-urban area of Madhya pradesh, India. Asian Pac J Cancer Prev $.2009 ; 10$ (6): 1113-1117.

23. Ferlay J, Soerjomataram I, Dikshit R, Eser S, Mathers C, Rebelo M. et al. Cancer incidence and mortality worldwide: sources, methods and major patterns in GLOBOCAN 2012. International journal of cancer. 2015 Mar 1; 136(5).

24. Nustus WP, Mikhail BI. Factors Associated with Breast Self-Examination among Jordanian Women .Public Health Nursing .2002; 19(4): 263-271.

25. Chioma C, Asuzu SR. knowledge attitude and practice of breast self-examination among the female students of the University Of Ibadan, Nigeria. Pakistan journal of social science.2007; 4(3):400-402.

Table (1): Comparison of pre-and post-intervention breast cancer and BSE knowledge 


\begin{tabular}{|c|c|c|c|}
\hline & $\begin{array}{l}\text { (120) } \\
\text { Median } \\
\text { max) }\end{array}$ & $\begin{array}{l}\text { Median (min- } \\
\text { max) }\end{array}$ & \\
\hline \multicolumn{4}{|l|}{ Knowledge about breast cancer } \\
\hline $\begin{array}{l}\text { Total breast cancer } \\
\text { knowledge }\end{array}$ & $5(1-17)$ & $7(3-22)$ & $\mathrm{Z}=5.9, \mathrm{P} \leq 0.001$ \\
\hline - General knowledge & $1(0-3)$ & $3(0-7)$ & $\mathrm{Z}=8.5, \mathrm{P} \leq 0.001$ \\
\hline - Early possible clinical presentation & $1(0-6)$ & $1(0-6)$ & $\mathrm{Z}=3.2, \mathrm{P}=0.001$ \\
\hline - Possible risk factors & $3(0-13)$ & $3(0-13)$ & $\mathrm{Z}=2.5, \mathrm{P}=0.013$ \\
\hline \multicolumn{4}{|l|}{ Knowledge about BSE } \\
\hline Total BSE knowledge & $3(0-7)$ & $5(3-9)$ & $\mathrm{Z}=9.5, \mathrm{P} \leq 0.001$ \\
\hline $\begin{array}{l}\text { - General knowledge } \text {,proper } \\
\text { timing, proper age of starting } \\
\text { \&frequency }\end{array}$ & $1(0-2)$ & $2(0-3)$ & $\mathrm{Z}=7.8, \mathrm{P} \leq 0.001$ \\
\hline - Knowledge about technique & $2(0-6)$ & $3(2-7)$ & $\mathrm{Z}=9.7, \mathrm{P} \leq 0.001$ \\
\hline
\end{tabular}

Table (2): Comparison of pre- and post-intervention health belief model (HBM) main constructs and BSE practice scores

\begin{tabular}{|c|l|l|l|}
\hline HBM main constructs & $\begin{array}{l}\text { Pre-test score } \\
\text { Median }\end{array}$ & $\begin{array}{l}\text { Post-test score } \\
\text { max) }\end{array}$ & Significance \\
max) & $($ min- & \\
\hline - $\quad$ Perceived susceptibility to BC & $4(0-8)$ & $5(0-8)$ & $\mathrm{Z}=5.3, \mathrm{P} \leq 0.001$ \\
\hline - $\quad$ Perceived severity of BC & $13(0-21)$ & $12(3-22)$ & $\mathrm{Z}=1.6, \mathrm{P}=0.11$ \\
\hline - $\quad$ Perceived benefits of screening \& BSE & $8.33 \pm 2.47$ & $9.19 \pm 1.32$ & $\mathrm{t}=5.7, \mathrm{P} \leq 0.001$ \\
\hline - $\quad$ Perceived barriers to screening \& BSE & $3(0-10)$ & $1(0-8)$ & $\mathrm{Z}=8.2, \mathrm{P} \leq 0.001$ \\
\hline - $\quad$ Perceived cues to action to BSE & $9(0-20)$ & $12(3-20)$ & $\mathrm{Z}=7.8, \mathrm{P} \leq 0.001$ \\
\hline - Perceived self-efficacy to BSE & $2(0-12)$ & $8(1-12)$ & $\mathrm{Z}=9.2, \mathrm{P} \leq 0.001$ \\
\hline Total HBM score*(mean \pm SD) & $32.85 \pm 7.23$ & $43.73 \pm 5.49$ & $\mathrm{t}=22.1, \mathrm{P} \leq 0.001$ \\
\hline BSE practice $(\mathrm{n}=28)$ & $0(0-1)$ & $1(0-1)$ & $\mathrm{Z}=3.6, \mathrm{P}<0.001$ \\
\hline
\end{tabular}

Z for Wilcoxon test

$\mathrm{t}=$ Paired $\mathrm{t}$ test

Table (3): Variation of pre-intervention knowledge, practice and HBM main constructs scores according to age and education 


\begin{tabular}{|c|c|c|c|c|}
\hline Pre-intervention & $\begin{array}{l}\text { Total } \\
\text { knowledge } \\
\text { score } \\
\text { Median (min- } \\
\text { max) }\end{array}$ & $\begin{array}{l}\text { Total BSE } \\
\text { knowledge } \\
\text { Score } \\
\text { Median (min- } \\
\text { max) } \\
\end{array}$ & $\begin{array}{l}\text { Total } \\
\text { Practice score } \\
\text { Median (min- } \\
\text { max) }\end{array}$ & $\begin{array}{l}\text { HBM total } \\
\text { score } \\
(\text { mean } \pm \text { SD })\end{array}$ \\
\hline $\begin{array}{l}\text { Age (years): } 20- \\
30- \\
40- \\
50-60\end{array}$ & $\begin{array}{l}6(1-15) \\
5(1-17) \\
4(1-11) \\
7(2-16)\end{array}$ & $\begin{array}{l}3(0-7) \\
3(0-6) \\
3(0-5) \\
4(1-6)\end{array}$ & $\begin{array}{l}0(0-1) \\
0 \\
0(0-1) \\
1(1-1)\end{array}$ & $\begin{array}{l}32.97 \pm 7.32 \\
32.7 \pm 8.08 \\
31.23 \pm 9.3 \\
34 \pm 8.43\end{array}$ \\
\hline Significance & $\begin{array}{l}\mathrm{KW} \chi^{2}=4.64, \mathrm{P}= \\
0.2\end{array}$ & $\begin{array}{l}\mathrm{KW} \chi^{2}=4.72, \mathrm{P}= \\
0.2\end{array}$ & $\begin{array}{l}\mathrm{KW} \chi^{2}=7.48, \mathrm{P}=0 . \\
058\end{array}$ & $\mathrm{~F}=0.3, \mathrm{P}=0.8$ \\
\hline $\begin{array}{l}\text { Education: } \\
\text { Secondary school } \\
\text { University } \\
\text { graduate } \\
\text { Higher education }\end{array}$ & $\begin{array}{l}6(1-16) \\
5(1-15) \\
8(2-17)\end{array}$ & $\begin{array}{l}3.5(0-7) \\
3(0-7) \\
3(1-6)\end{array}$ & $\begin{array}{l}0(0-1) \\
0(0-1) \\
0(0-1)\end{array}$ & $\begin{array}{l}32.84 \pm 7.84 \\
32.76 \pm 7.95 \\
33.16 \pm 7.07\end{array}$ \\
\hline Significance & $\begin{array}{l}\mathrm{KW} \chi^{2}=6.77, \mathrm{P}= \\
0.03\end{array}$ & $\begin{array}{l}\mathrm{KW} \chi^{2}=1.1, \mathrm{P}=0 \\
6\end{array}$ & $\begin{array}{l}\mathrm{KW} \chi^{2}=0.63, \mathrm{P}=0 . \\
7\end{array}$ & $\begin{array}{l}\mathrm{F}=0.02, \mathrm{P}=0.9 \\
8\end{array}$ \\
\hline
\end{tabular}

$\mathrm{KW}=$ Kruskal-Wallis

F for one way ANOVA test 
التوعية الصحية وممارسة الكشف المبكر عن سرطان الثدي: دراسة تدخلية في مجموعة من النساء المصريات العاملات

هند محمد- نادبه منتصر -عمر فاروق- نرمبن نبازى- عبد الهادى جيلانى

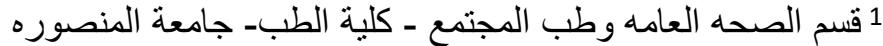

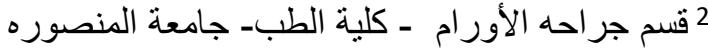

سرطان الثذي هو أكثر أنواع السرطان انتثار ابين النساء في جميع أنحاء العالم ,والسبب الرئيسي للوفاة من بين جميع أنو اع السرطان التي تصيب تلك الفئة. ويظل الكثف المبكر عن سرطان الثدي حجر الزاوية لمكافحة المرض وتحسين نتائجها و هذه الدراسة كانت تهدف الى:تقييم المعرفة والاتجاهات مستخدمين نموذج المعتقدات الصحية عن مدي خطورة وانتشار مرض سرطان الثذي و الاكتشاف المبكر له وعن مدي ممارسة الفحص الذاتي للثدي قبل وبعد تقديم برنامج تثقيف صحى في عينة من الموظفات بجامعة المنصورةثقيميم مدى تأثير برنامج تثقيف صحى على تحسين الممارسة السليمة للفحص الذاتي للثدي قبل وبعد نطبيق البرنامج .تم اجراء هذه الدراسة في جامعة المنصورة على 120 من موظفات الجامعة وعن طريق استخدام دراسة تداخلية تتكون من ثلاثه مر احل : المرحلة الأولى :وصفية ؛

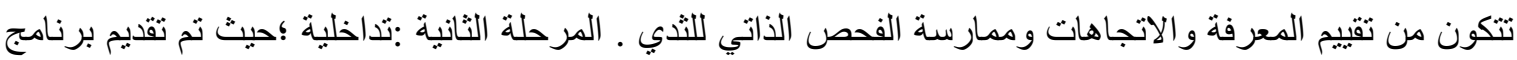
تثقيف صحى عن سرطان الثذي والكثف المبكر عنه و الفحص الذاتي للثدي. . المرحلة الثالثة :تم قياس التغير في المعرفة و الاتجاهات تجاه سرطان الثدي و الاكتشاف المبكر له و الفحص الذاتي للثني وممارسة الفحص الذاتي للثدي في نفس العينة بعد شهر من المقابلة بعد أن تقوم كل سيدة بعمل الفحص الذاتي للثدي لنفسها في المنزل.من الدراسة السابقة وجد ان مستوى المعرفة فيما يخص سرطان الثذي ,طرق الاكتشاف المبكر لسرطان الثدي والفحص الذاتي للثذي ضعيف جدا في مرحلة ما قبل تقديم البرنامج التثقيفي وقد وجد انه وبعد تقديم برنامج تثقيف صحى ان كل من مستوى المعرفة والاتجاهات نحو سرطان الثدي ,طرق الاكتشاف المبكر والفحص الذاتي للثني وممارسة الفحص الذاتي تم تحسنه بشكل ملحوظ بعد تطبيق البرنامج التثقيفي ـ ولذا نوصي بما يلى :تقديم برنامج تعليم صحي شامل يستهدف سرطان الثدي والكثف المبكر له و الممارسة السليمة للفحص الذاتي للثدي. تشجيع دور وسائل العالم في التو عية حول سرطان الثدي و الكثف المبكر له و الفحص الذاتي للثدى. تثجيع القيام بمزيد من الدراسات للكثف عن وجود أي ارتباط ما بين الخصائص الديموغر افية ومستوى المعرفة والاتجاهات والممارسة عن سرطان الثذي , الاكتشاف المبكر لسرطان الثذي و الفحص الذاتي للثدي. 